\title{
EFFECT OF ACACIA SALIGNA LEVELS ON LACTATING BARKI EWES PERFORMANCE
}

\author{
H. M. Khattab ${ }^{2}$; S. M. Shawket ${ }^{1}$; A. M. Abdel-Wahed ${ }^{1}$; A. M. Mansour ${ }^{2}$ and B.R. \\ Younan ${ }^{1}$ \\ ${ }^{1}$ Animal Nutrition Department, Desert Research Centre, Egypt \\ ${ }^{2}$ Animal Production Department, Agric. Faculty, Ain Shams Univ., Egypt
}

(Received 19/9/2017, accepted 22/11/2017)

\section{SUMMARY}

$\mathrm{T}$

This study was conducted to evaluate the effect of feeding graded levels of Acacia saligna leaves hay (ALH) on dry matter intake, milk yield, composition and lambs growth rate from birth to weaning. Forty Barki ewes at the start of lactation stage averaged 3-5 years old with an average live body weight $38.8 \pm 1.6 \mathrm{~kg}$ were randomly allocated to four treatments groups (ten ewes per group), were fed with $0,20,40$ and $60 \%$ of ALH as berseem hay replacement. The experiment lasted 16 weeks and showed that there was no significant difference $(\mathrm{P}>0.05)$ in daily dry matter intake ewes body weight change, milk yield and compositions and lambs daily gain during lactation season due to the supplementation of lactating ewes with graded levels of ALH compared with control treatment. Milk yield values were 24.1, 23.9, 24.2 and 24.3 g/d and ADG values were 147.3, 145.5, 152.7 and 150.9 g/d for control, 20, 40 and 60\% ALH, respectively. It may be concluded that $A$. saligna leaves hay can be used as alternative feed sources for lactating ewes.

Key words: Lactating ewes, feed intake, milk yield, milk composition, lambs daily gain.

\section{INTRODUCTION}

Acacia saligna (Labill.) H.L. Wendl. is an adapted evergreen species with appropriate characteristics for cultivation in the dry coastal area (Squella et al., 1985; Mora and Meneses, 2003 and Meneses, 2004). Normally farmers use this resource to feed sheep and goats, especially during summer and autumn. They harvest Acacia leaves and stems from young and mature trees during the dry season to provide a daily supplement to grazing.

However, Acacia contains $28.9 \mathrm{~g} \mathrm{~kg}-1$ of total tannins, which have anti-nutritive activity in ruminal digestion. This component links dietary protein and makes nutrients less digestible in the rumen, limiting microbial growth, amino acid microbial synthesis and reduces the absorption of amino acids in the intestine (Pritchard et al., 1992; Ben Salem et al., 2008).

For lactating animals, it is considered that about 25 to $35 \%$ of protein intake will be converted to proteins in milk (Lapierre et al., 2002) while the rest will be excreted in urine (35-45\%) or feces (30$40 \%$ ), therefore it is reasonable to search ways to reduce these losses. Indeed, proper use of $\mathrm{N}$ from feeds reduced $\mathrm{N}$ discharges into the environment. In addition, environmental pressures are increasing on livestock production systems. Nitrogen excreted by ruminants, in particular, contributes to groundwater pollution. Protein supplementation for sheep fed protein deficient ration leads to an increase of protein quantity secreted in milk (Bocquier and Caja, 2001; Atti and Rouissi, 2003). However, pasture grass is characterized by its lushness of soluble $\mathrm{N}$ fermentable in the rumen resulting in a decrease in $\mathrm{N}$ retention. As a solution, the protection of proteins from microbial degradation in the rumen by chemical treatment was often used; however the use of formaldehyde is increasingly rejected because of the possible toxicity, indeed a positive correlation between oral administration of formaldehyde and its presence in the milk has been found on dairy cows and goats (Buckley et al., 1988; Barry and Tome, 1991). The protection of proteins by natural products like tannins present in local feed resources could increase the retention of $\mathrm{N}$ without negative repercussion (Terril et al., 1992). 
The objective of this study was to evaluate the use of different levels of Acacia levels hay on ewes feed intake, body weight change, milk production and the offspring lambs weaning weight.

\section{MATERIALS AND METHODS}

The present study was conducted at Marryot Research Station, Desert Research Center, Ministry of Agriculture, $35 \mathrm{Km}$ south of Alexandria, Egypt during 4014-2015.

\section{Acacia saligna hay preparation:}

Enough amounts of the fresh Acacia leaves (AL) were collected from the farm of Marryot Station and Borg El-Arab Road and chopped to 3-5 cm length. After chopping, Acacia leaves were dried at shaded aria for 3-4 days by spreading on plastic sheets, (air-drying). Samples of hay were taken for subsequent proximate chemical analyses.

\section{Animals and management:}

Forty Barki ewes at the start of lactation stage averaged 3-5 years old with an average live body weight $38.8 \pm 1.6 \mathrm{~kg}$ were randomly allocated to four treatments groups (ten ewes per group); each group was housed separately in shaded $5 \times 5$ meter pens and fed their normal allowances according to the experimental assignment during the lactation period. Feeds were offered twice daily at 9:00 am. and 5:00 pm. Fresh tap water was made available for free-choice drinking once daily after the morning feeding. Refusals were collected the following morning, weighed and sampled, and daily intake was recorded. The experimental animals were kept under the same managerial and hygienic condition. Before beginning the experiment animals were treated against internal and external parasites and intro-toxemia.

Birth and individual kid body weight was considered and evaluated every 14 days until weaning. During lactation period, daily milk yield was measured biweekly starting from the second week of lambing till the $25^{\text {th }}$ week of lactation using the standard hand-milking procedure after separation of lambs from their dams. Milk samples were collected biweekly for chemical analysis till the $25^{\text {th }}$ week.

\section{Experimental diets and feeding trial:}

The requirements of digestible $\mathrm{CP}$ and metabolizable energy (ME) need during the lactation period of ewes were calculated according to the recommended feeding standards of Kearl (1982). The experimental diets were prepared to replace berseem hay by $0 \%$ (Control), 20\% (20\% ALH), 40\% (40\% ALH) and $60 \%$ (60\% ALH) Acacia saligna leaves hay. The compositions and chemical analysis of diets are presented in Tables (1) and (2). Proximate analysis of feeds and milk samples were determined according to the procedure of A.O.A.C. (1995).

Table (1): Composition (\%, on DM basis) of ewe's experimental diets.

\begin{tabular}{lcccc}
\hline \multirow{2}{*}{ Ingredient } & \multicolumn{4}{c}{ Experimental Diets } \\
\cline { 2 - 5 } & Control & $20 \%$ ALH & $40 \%$ ALH & $60 \%$ ALH \\
\hline CFM* & 36.0 & 36.0 & 36.0 & 36.0 \\
Yellow corn & 24.0 & 24.0 & 24.0 & 24.0 \\
Berseem hay & 40.0 & 32.0 & 24.0 & 16.0 \\
Acacia saligna leaves & 0.0 & 8.0 & 16.0 & 24.0 \\
\hline
\end{tabular}

"CFM: Commercial concentrate feed mixture

Table (2): Chemical analysis (\%, on DM basis) of the experimental diets.

\begin{tabular}{lrrrc}
\hline \multirow{2}{*}{ Item } & \multicolumn{4}{c}{ Experimental Diets } \\
\cline { 2 - 5 } & Control & $20 \%$ ALH & $40 \%$ ALH & $60 \%$ ALH \\
\hline DM & 90.3 & 89.8 & 91.2 & 91.1 \\
OM & 90.0 & 89.8 & 90.1 & 90.3 \\
CP & 12.0 & 11.8 & 11.6 & 11.9 \\
CF & 17.0 & 16.8 & 17.0 & 15.7 \\
EE & 3.5 & 3.4 & 3.5 & 3.6 \\
NFE & 57.5 & 57.8 & 58.0 & 59.1 \\
Ash & 10.0 & 10.2 & 9.9 & 9.7 \\
\hline
\end{tabular}


DM: Dry matter; OM: organic matter; CP: crude protein; $C F$ : crude fiber; EE: ether extract; NFE: nitrogen free extract.

\section{Statistical analysis:}

Data were statistically analyzed using the method of least squares analysis of variance using software SPSS 10.0 windows (SPSS, 1999). Differences in mean values between groups were compared by Duncan's Multiple Range Test (Duncan, 1955).

\section{RESULTS AND DISCUSSION}

\section{Feed intake and nutritive value:}

Feed intake by Barki lactating ewes fed the experimental diets is presented in Table (3). Results indicated that DM (g/h/day) and digestible nutrient intake (TDNI, g/h/day) of lactating ewes did not influenced significantly $(\mathrm{P}>0.05)$ by the level of ALH replacement. However, the inclusion of graded levels of ALH in the diets of lactating ewes increased significantly $(\mathrm{P}<0.05)$ DCP intake $(\mathrm{g} / \mathrm{h} / \mathrm{day})$ compared to control (135.8, 133.6 and $137.1 \mathrm{vs.} 130.1 \mathrm{~g} / \mathrm{h} /$ day, respectively) while differences between DCP intake values of lactating ewes fed $20 \%$ and $40 \%$ ALH diets were not significant.

Table (3): Effect of treatments on feed intake (g/h/day) and nutritive values of the experimental diets fed to the lactating Barki ewes (Means $\pm \mathrm{SE}$ ).

\begin{tabular}{lccccc}
\hline & \multicolumn{5}{c}{ Experimental Diets } \\
\cline { 2 - 5 } Item & Control & $20 \%$ ALH & $40 \%$ ALH & $60 \%$ ALH & P - value \\
\cline { 2 - 5 } $\begin{array}{l}\text { Con. } \\
\text { mixture }\end{array}$ & $599.8 \pm 30.41$ & $596.8 \pm 25.86$ & $593.7 \pm 28.99$ & $615.8 \pm 25.98$ & ---- \\
$\begin{array}{l}\text { Yellow } \\
\text { corn }\end{array}$ & $310.3 \pm 29.83$ & $298.4 \pm 28.44$ & $296.8 \pm 24.87$ & $307.9 \pm 29.11$ & ---- \\
B. hay & $590.7 \pm 36.32$ & $477.7 \pm 31.66$ & $356.4 \pm 33.40$ & $246.5 \pm 32.33$ & --- \\
ALH & ----- & $119.4 \pm 12.89$ & $237.6 \pm 10.68$ & $369.7 \pm 10.91$ & --- \\
TDMI & $1500.8 \pm 40.54$ & $1492.3 \pm 39.76$ & $1484.6 \pm 36.52$ & $1540.0 \pm 40.01$ & 0.710 \\
TDNI & $1032.6 \pm 28.56$ & $1017.8 \pm 30.02$ & $1021.4 \pm 27.66$ & $1058.0 \pm 30.31$ & 0.730 \\
DCPI $^{*}$ & $130.1^{\mathrm{b}} \pm 12.10$ & $135.8^{\mathrm{ab}} \pm 14.88$ & $133.6^{\mathrm{ab}} \pm 11.32$ & $137.1^{\mathrm{a}} \pm 12.10$ & 0.046 \\
\hline
\end{tabular}

Con. Mixture: Concentrate mixture, B. hay: Berseem hay, ALH: Acacia leaves hay, TDMI: Total dry matter intake. TDN: Total digestible nutrients and DCP: Digestible crude protein *(were calculated according to the nutritive values of the experimental diets, data under publication).

$a, b, c$, Means in the same raw with different superscripts are differ significantly $*(P<0.05)$

In this respect, Maamouri et al. (2011) conducted study to evaluate the effects of natural protection of protein from microbial degradation in the rumen by Acacia tannins on DM intake and milk production in dairy ewes. The experimental sheep flock grazing rye grass pasture was divided into four groups. Indoor, animals were supplemented with $300 \mathrm{~g}$ of concentrate, $300 \mathrm{~g}$ of concentrate $+100 \mathrm{~g}$ Acacia cyanophylla foliage (Acacia), $300 \mathrm{~g}$ of concentrate $+200 \mathrm{~g}$ Acacia for C, C1A, C2A groups, respectively, and only 100 $\mathrm{g}$ of Acacia for group A. They indicated that total DM intake of ewes receiving concentrate and Acacia supplement was significantly higher $(\mathrm{P}<0.001)$ than the intake of ewes receiving only concentrate $(300 \mathrm{~g})$ which was higher than that of ewes receiving only Acacia $(100 \mathrm{~g})$.

At the same trend, Meneses et al., (2012) fed lactating ewes on 0, 25, 50, 75, and 100\% of Acacia as alfalfa (Medicago sativa L.) hay replacement in a completely randomized design. They found that DM, $\mathrm{CP}$, and $\mathrm{ME}$ intake were increased $(\mathrm{P}<0.01)$ in the lactation stage over the control with a high percentage of Acacia in the diet, which differed from the results during pregnancy. In the latter period, the lower 
Acacia intake can be attributed to the fetus, which reduced abdominal space, and to the low digestibility of this diet due to $\mathrm{N}$ fixation and ruminal ammonia by tannins, reducing rumen bacterial amino acid synthesis (Ben Salem et al., 2002; 2005; Krebs et al., 2007).

The lack of significantly in DM intake in the present study may be due to the low concentration of condensed tannins (TC) in the DM of the three levels of ALH consumption. Whereas, Frutos et al. (2009) reported that until fairly recently, most researchers believed that the consumption of tannins reduced voluntary feed intake. However, at present we have much more information, and are able to make more refined statements about tannins, their doses and their effects on the species that consume them, etc. It would appear that the consumption of plant species with high CT contents (generally $>50 \mathrm{~g} \mathrm{~kg}^{-1}$ of dry matter, DM) significantly reduces voluntary feed intake, while medium or low consumption $\left(<50 \mathrm{~g} \mathrm{~kg}^{-}\right.$ ${ }^{1}$ DM) seems not to affect it (Barry and Duncan, 1984; Barry and Manley, 1984; Waghorn et al., 1994a). It was previously reported that CT concentrate content in dried Acacia saligna leaves ranged from 31.5 (Maamouri et al., 2011) to $36 \mathrm{~g} / \mathrm{kg}$ dry matter (DM) (Ben Salem et al., 2002). According to these determinations, the expected calculated CT content related to the three levels of ALH used in the present study will be equivalent to $3.78-4.32,7.56-8.64$ and $11.66-13.32$ g CT for 20, 40 and 60\% ALH replacement of berseem hay, respectively. These values are in accord with Min et al. (2003) and Frutos et al. (2004) recommendations.

\section{Ewe's body weight change:}

Results of the effect of feeding diets containing different levels of dried Acacia saligna leaves (20, 40 and $60 \%$ ) instead of berseem hay on live body weight of Barki ewes during the lactation season are presented in Table (4) and Fig. (1). Initial body weight of lactating Barki ewes ranged from 38.4 to 39.5 $\mathrm{Kg}$ with no significant differences among treatments, which means a random distribution of the ewes on the different treatments. The results showed that the incorporation of ALH instead of berseem hay in the experimental diets at levels of 20\%, 40 and 60\% resulted in non-significant differences in live body weight at all the lactation season periods $(2,4,6,8,10,12,14$ and 16 weeks). It was noticeable that all the four groups of lactating ewes fed control and treated experimental diets with different ALH levels showed a leaner decrease in the values of their body weight every two weeks during the lactation season period (16 weeks).

Table (4): Effect of treatments on ewe's body weight changes.

\begin{tabular}{|c|c|c|c|c|c|}
\hline \multirow{2}{*}{ Items } & \multicolumn{4}{|c|}{ Experimental Diets } & \multirow{2}{*}{$\begin{array}{c}\mathrm{P}- \\
\text { value }\end{array}$} \\
\hline & Control & $20 \%$ ALH & $40 \% \mathrm{ALH}$ & $60 \% \mathrm{ALH}$ & \\
\hline At start & $38.6 \pm 1.68$ & $38.4 \pm 1.68$ & $38.6 \pm 1.22$ & $39.5 \pm 1.45$ & 0.208 \\
\hline $2^{\text {nd }}$ week & $38.6 \pm 1.88$ & $38.4 \pm 1.60$ & $38.6 \pm 1.55$ & $39.5 \pm 1.22$ & 0.263 \\
\hline $4^{\text {th }}$ week & $38.4 \pm 1.52$ & $38.2 \pm 1.81$ & $38.4 \pm 1.26$ & $39.3 \pm 1.84$ & 0.298 \\
\hline $6^{\text {th }}$ week & $38.1 \pm 1.76$ & $38.0 \pm 2.05$ & $37.9 \pm 1.38$ & $39.0 \pm 1.53$ & 0.387 \\
\hline $8^{\text {th }}$ week & $38.0 \pm 2.08$ & $38.4 \pm 1.81$ & $37.6 \pm 2.07$ & $38.9 \pm 1.39$ & 0.340 \\
\hline $10^{\text {th }}$ week & $38.3 \pm 1.46$ & $37.8 \pm 1.67$ & $37.4 \pm 1.80$ & $39.2 \pm 1.32$ & 0.488 \\
\hline $12^{\text {th }}$ week & $37.8 \pm 1.53$ & $37.8 \pm 1.55$ & $37.1 \pm 1.65$ & $39.6 \pm 1.65$ & 0.389 \\
\hline $14^{\text {th }}$ week & $37.6 \pm 2.17$ & $37.4 \pm 2.12$ & $37.0 \pm 1.22$ & $39.0 \pm 1.82$ & 0.413 \\
\hline $16^{\text {th }}$ week & $37.0 \pm 1.55$ & $36.6 \pm 1.85$ & $37.0 \pm 1.49$ & $38.0 \pm 1.33$ & 0.512 \\
\hline $\begin{array}{l}\text { Body weight } \\
\text { change, } \mathrm{Kg}\end{array}$ & $-1.6 \pm 0.58$ & $-1.8 \pm 0.52$ & $-1.6 \pm 0.61$ & $-1.5 \pm 0.73$ & 0.311 \\
\hline
\end{tabular}

Also the body weight changes of lactating Barki ewes at the end of lactation season and weaning of the offspring show the same trend as cleared previously. The lost values of body weight of lactating ewes fed control, 20, 40 and 60\% ALH diets (- 1.6, -1.8, -1.6 and $-1.5 \mathrm{Kg}$, respectively) from the start to the end of lactation season and weaning of offspring may be due to that the nursing lambs beyond the age of 
6 - 8 weeks consume increasing amounts of concentrates (and possibly hay) as indicated by Farid et al. (2005 a and b) and represent serious competition to their dams.

\section{Milk yield:}

Results of Table (5) showed that the incorporation of 20 or 40 or $60 \%$ ALH instead of berseem hay in lactating ewes diets did not affect significantly the daily milk yield $(215.5,210.7,215.6$ and $216.6 \mathrm{ml} /$ day for control, 20, 40 and 60\% ALH ewe groups, respectively) or total milk production (24.1, 23.9, 24.2 and 24.3 Littre/16 weeks for control, 20, 40 and 60\% ALH ewe groups, respectively).

Table (5): Effect of feeding treatments on milk production.

\begin{tabular}{lccccc}
\hline \multirow{2}{*}{ Item } & \multicolumn{5}{c}{ Experimental Diets } \\
\cline { 2 - 5 } & Control & $20 \%$ ALH & $40 \%$ ALH & 60\% ALH & \\
\hline Length of lactation, & 112 & 112 & 112 & 112 & ---- \\
days & $180.0 \pm 0.43$ & $177.0 \pm 0.45$ & $197.4 \pm 0.64$ & $181.7 \pm 0.48$ & 0.367 \\
0-2 weeks & $310.5 \pm 0.37$ & $300.0 \pm 0.62$ & $286.7 \pm 0.77$ & $282.0 \pm 0.60$ & 0.287 \\
2-4 weeks & $295.2 \pm 0.56$ & $270.0 \pm 0.52$ & $278.2 \pm 0.68$ & $265.1 \pm 0.53$ & 0.467 \\
4-6 weeks & $252.2 \pm 0.51$ & $248.4 \pm 0.80$ & $219.3 \pm 0.48$ & $244.4 \pm 0.72$ & 0.775 \\
6-8 weeks & $225.5 \pm 0.66$ & $207.3 \pm 0.51$ & $198.7 \pm 0.64$ & $217.9 \pm 0.54$ & 0.393 \\
8-10 weeks & $180.0 \pm 0.58$ & $180.0 \pm 0.55$ & $184.0 \pm 0.55$ & $207.0 \pm 0.68$ & 0.720 \\
10-12 weeks & $151.2 \pm 0.44$ & $162.6 \pm 0.33$ & $177.0 \pm 0.73$ & $188.6 \pm 0.55$ & 0.654 \\
12-14 weeks & $138.6 \pm 0.52$ & $140.4 \pm 0.47$ & $151.1 \pm 048$ & $143.3 \pm 0.70$ & 0.771 \\
14-16 weeks & $215.5 \pm 0.65$ & $210.7 \pm 0.48$ & $215.6 \pm 0.71$ & $216.6 \pm 0.54$ & 0.686 \\
Average daily milk & $24.1 \pm 2.13$ & $23.9 \pm 2.56$ & $24.2 \pm 2.84$ & $24.3 \pm 2.77$ & 0.711 \\
yield, ml & & & &
\end{tabular}

Although, there are no significant differences between the total milk production (L/16 weeks) values of the experimental ewe groups due to increasing the incorporation of ALH instead of berseem hay, but it is noticeable that, ewes in $60 \%$ group produced the higher value of total milk production during the lactation season period followed by $40 \% \mathrm{ALH}$, control and then $20 \%$ ALH ewe groups, as indicated in Table (5). Lactation curves of the four groups are illustrated in Figure (2). In all, peak lactation was observed during the second week of lambing. The $60 \%$ ALH ewes group showed better persistency throughout as compared to other experimental groups. 


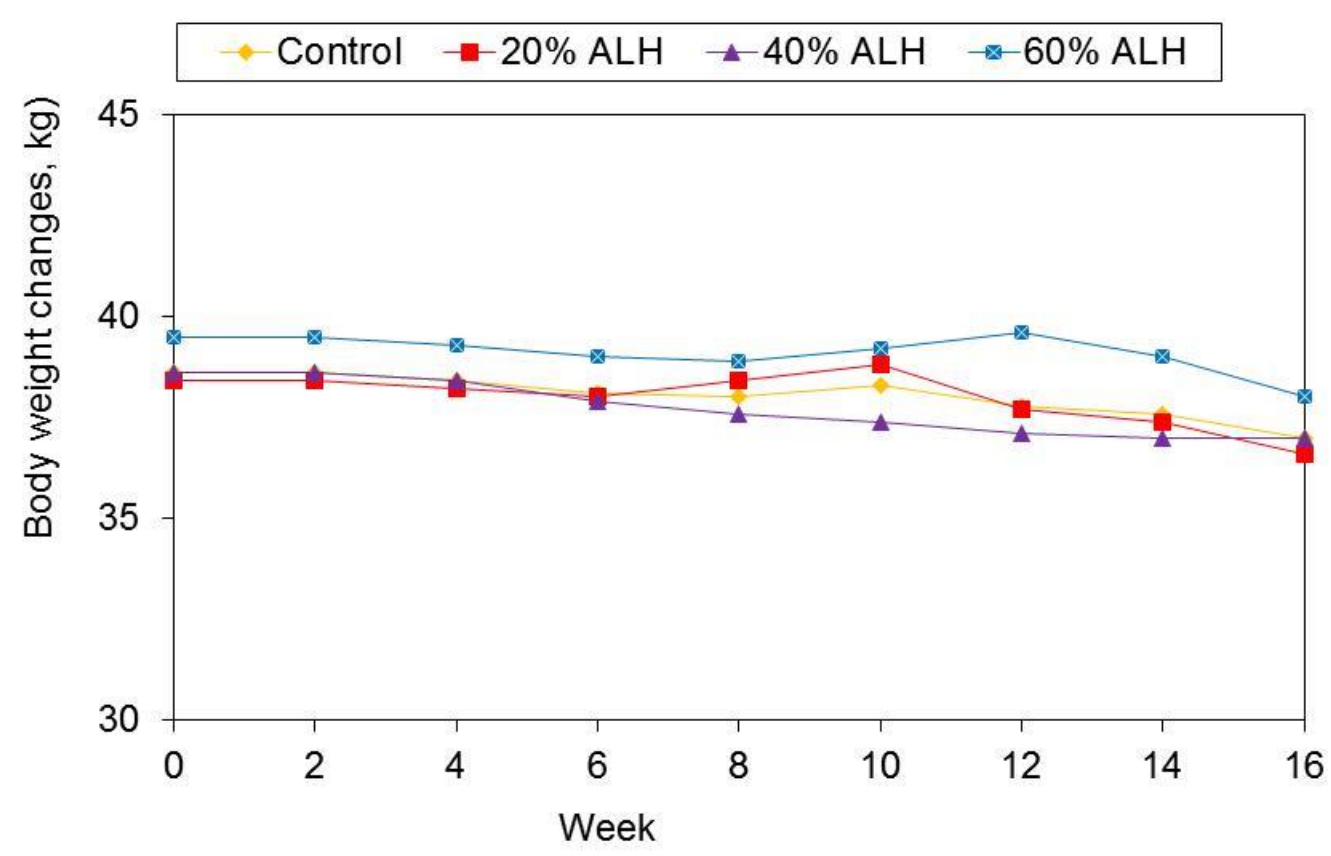

Figure (1): Body weight change of ewes fed with different levels of Acacia saligna leaf hay in the diet during lactation period.

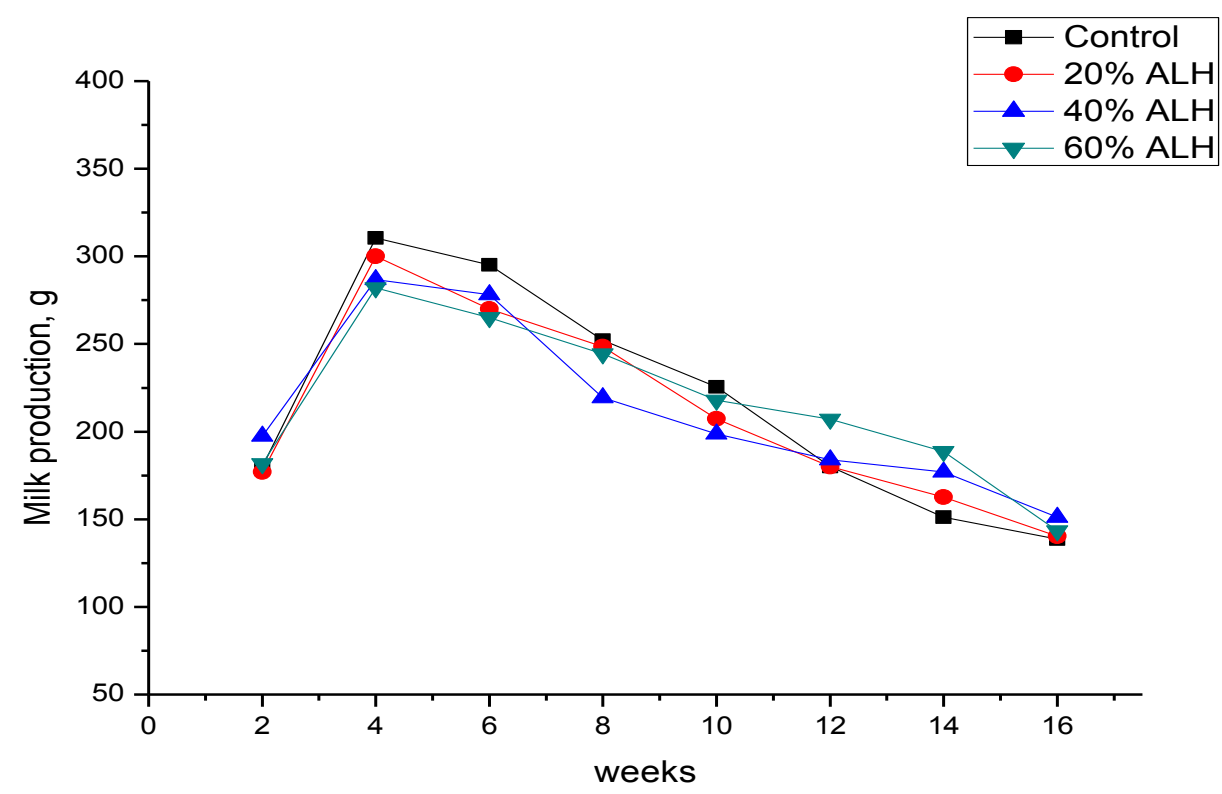

Figure (2): Length of lactation and daily milk production of ewes feeding graded levels of Acacia saligna leaf hay (ALH).

Vasta et al. (2008) reported that condensed tannins in high concentrations generally have adverse effects on animal performance. However, moderate concentrations might have positive effects. Indeed, Wang et al. (1996) studied the effect of CT on sheep milk yield, comparing ewes grazing Lotus corniculatus, which contained moderate amounts of CT (44.5 g/kg DM), supplemented or not with PEG. Treatments did not affect milk yield until the 5th week of lactation, while from the 6th to the 11th week milk yield was significantly higher in the ewes receiving the diet without PEG. When lactating Sarda ewes grazed either on annual ryegrass (Lolium rigidum Gaudin) or sulla (CT: 20-40 g/kg DM), no differences in milk yield and composition were observed in early spring, while the milk yield of the sullafed ewes was significantly higher than that of ryegrass-fed ones (1122 g/d versus $615 \mathrm{~g} / \mathrm{d}$, respectively) in 
mid spring (Molle et al., 2003). Milk yield was the highest for C1A group $(555 \mathrm{ml} / \mathrm{day})$ and the lowest for A group (500 ml/day). This is in agreement with other studies (D'Urso et al., 1993; Purroy and Jaime, 1995; Rouissi et al., 2005), in which supplementation with concentrate for grazing ewes increased milk production. Acacia supply did not improve ( $>0.05$ ) milk production. The protection of protein from microbial degradation in the rumen by tannins of the Acacia did not result in milk increase; there was only a slight superiority for milk production in the $\mathrm{C} 1 \mathrm{~A}$ group compared to the $\mathrm{C}$ one. These results of Acacia supplementation effect on milk production are in agreement with our present results of milk production. Similarly, Zegeye et al. (2016) indicated that feeding A. saligna leaves increased milk yield which implied that the tree can be used as alternative sources of feed for dairy animals. The findings were in line with Steinshamn (2010) who reported that legumes increased milk yield than grass based feeding.

On the contrary, Meneses et al. (2012) used goats on 0, 25, 50, 75, and 100\% of Acacia as alfalfa (Medicago sativa L.) hay replacement. The milk production for 0 and $25 \%$ treatments were the same but different from those for the other treatments, which were 160.24, 163.35, 128.18, 125.92, and $66.48 \mathrm{~L}$, respectively for the $0,25,50,75$ and $100 \%$ treatments. These results indicate that the progressive increasing percentage level of Acacia saligna instead of alfalfa hay decreased significantly $(\mathrm{P}<0.01)$ milk production.

\section{Milk composition:}

Milk composition of lactating Barki ewes is presented in Table (6). Results indicated that increasing of the percentage level of ALH replacement instead of B. hay did not significantly affect the milk chemical composition.

Table (6): Milk chemical composition of lactating ewes fed diets contain different levels of ALH.

\begin{tabular}{lllccl}
\hline \multirow{2}{*}{ Item } & \multicolumn{5}{c}{ Experimental Diets } \\
\cline { 2 - 5 } & Control & $20 \%$ ALH & $40 \%$ ALH & $60 \%$ ALH \\
\hline TS\% & $16.7 \pm 0.50$ & $16.5 \pm 0.50$ & $16.5 \pm 0.50$ & $16.7 \pm 0.70$ & 0.552 \\
SNF\% & $12.6 \pm 0.60$ & $12.6 \pm 0.50$ & $12.4 \pm 0.90$ & $12.6 \pm 0.70$ & 0.496 \\
Fat\% & $4.1 \pm 0.30$ & $3.9 \pm 0.20$ & $4.1 \pm 0.20$ & $4.1 \pm 0.30$ & 0.407 \\
Ash\% & $1.0 \pm 0.06$ & $1.1 \pm 0.05$ & $1.1 \pm 0.05$ & $1.1 \pm 0.07$ & 0.513 \\
Protein\% & $6.4 \pm 0.30$ & $6.1 \pm 0.30$ & $6.2 \pm 0.30$ & $6.2 \pm 0.40$ & 0.458 \\
Lactose\% & $5.2 \pm 0.60$ & $5.2 \pm 0.60$ & $5.6 \pm 0.60$ & $4.9 \pm 0.80$ & 0.522 \\
\hline
\end{tabular}

The effect of tanniniferous feeds (like, Acacia spp.) on milk fat and protein composition varies markedly depending on the concentration of tannins present in the feeds. Condensed tannins in high concentrations generally have adverse effects on animal performance (Vasta et al. 2008). However, moderate concentrations might have positive effects. Indeed, Wang et al. (1996) studied the effect of CT on sheep milk composition, comparing ewes grazing Lotus corniculatus, which contained moderate amounts of CT $(44.5 \mathrm{~g} / \mathrm{kg} \mathrm{DM})$, supplemented or not with PEG. Treatments indicated that milk fat concentration was higher for the PEG supplemented group, which had the lowest milk yield. However, no differences were observed in milk protein concentration, despite the differences in milk yield.

Wang et al. (1996) stated that the use of feeds with low CT concentration reduced rumen protein degradation and increased both protein abomasal flow and essential AA absorption in the small intestine. This explanation is also supported by Barry and McNabb (1999). Moreover, Woodward et al. (2002) suggested a modification of rumen microbial population. When lactating Sarda ewes grazed either on annual ryegrass (Lolium rigidum Gaudin) or sulla (CT: $20-40 \mathrm{~g} / \mathrm{kg} \mathrm{DM}$ ), no differences in milk composition were observed in early spring, while the milk yield of the sulla-fed ewes was significantly higher than that of ryegrass-fed ones (1122 g/d versus $615 \mathrm{~g} / \mathrm{d}$, respectively) in mid spring (Molle et al., 2003). Despite this large difference in milk yield, which should have induced an evident dilution effect, milk fat and protein concentration did not differ between groups. This suggests that the CT of sulla did not depress milk production and probably helped to maintain high milk fat and protein concentration. 
The utilization of forages with low CT concentration increases milk yield and has positive effects on milk protein concentration and yield, due to a higher availability of essential amino acids. On the other hand, high concentrations of $\mathrm{CT}$ in alternative feed resources (AFR) markedly reduce rumen microbial activity and bacterial and feed amino acid digestion in the intestine because effects of tannins on ruminant productivity depend on the quality and quantity of dietary protein (Patra and Saxena, 2011). The present results are also in agreement with those of Zegeye et al. (2016) who reported that there was no significant difference in milk fat, lactose, solids not fat, density, protein and mineral content of dairy cows fed diets containing graded level of Acacia saligna leaves. Feeding A. saligna leaves did not affect milk composition but increased milk yield which implied that the tree can be used as alternative sources of feed for dairy animals. These findings also were in line with Steinshamn (2010) who reported that legumes increased milk yield than grass based feeding. Similarly, milk yield was higher for ewes fed higher level of AS leaves (Maamouri et al., 2011).

\section{Lambs body weight changes from birth to weaning:}

Results of the effect of feeding dried Acacia saligna leaf hay (A LH) at levels 20, 40 and 60\% instead of berseem hay on birth weight and biweekly body weight are presented in Table (7) and Figure (3). Neglecting the lambs sex, results showed that the inclusion of ALH instead of berseem hay at levels of 20,40 and $60 \%$ resulted in non-significant differences $(\mathrm{P}>0.05)$ in birth weight and body weight change from birth to weaning at all periods of the experiment $(2,4,6,8,10,12,14$ and 16 weeks).

The present birth weight values are lower than the average values (males and females) 3.7 and $3.9 \mathrm{Kg}$ of lambs born for Barki ewe dams fed ad lib berseem hay (according to NRC, 1985) and one- third hay plus ad lib rice straw respectively, and higher than the average birth weight $3.2 \mathrm{Kg}$ of lambs born for Barki ewe dams fed ad lib rice straw with added a commercial molasses-urea mixture (Farid et al., 2005c). Weaning weights of lambs (neglecting lamb's sex) are19.8, 19.6, 20.5 and 20.4Kg of lambs from dams fed control, 20, 40 and 60\% ALH diets, respectively. These values are almost nearly to the value of $21.8 \mathrm{Kg}$ for lams born from ewe dams fed according to NRC (1985) recommended allowances as recorded by Farid et al. $(2005 \mathrm{c})$.

Table (7): Effect of feeding treatments on lamb's body weight change from birth to weaning.

\begin{tabular}{|c|c|c|c|c|c|}
\hline \multirow{2}{*}{ Items } & \multicolumn{4}{|c|}{ Experimental diets } & \multirow{2}{*}{$\mathrm{P}$ - value } \\
\hline & Control & $20 \%$ ALH & $40 \%$ ALH & $60 \%$ ALH & \\
\hline Birth weight & $3.5 \pm 0.21$ & $3.4 \pm 0.19$ & $3.4 \pm 0.25$ & $3.5 \pm 0.27$ & 0.269 \\
\hline 2 weeks & $4.9 \pm 0.42$ & $4.9 \pm 0.35$ & $5.3 \pm 0.42$ & $5.6 \pm 0.33$ & 0.564 \\
\hline 4 weeks & $7.0 \pm 0.68$ & $7.5 \pm 0.73$ & $7.9 \pm 0.91$ & $8.3 \pm 0.79$ & 0.415 \\
\hline 6 weeks & $9.6 \pm 0.55$ & $10.1 \pm 0.88$ & $10.5 \pm 1.02$ & $10.9 \pm 0.50$ & 0.411 \\
\hline 8 weeks & $11.9 \pm 0.80$ & $12.4 \pm 0.70$ & $13.1 \pm 1.13$ & $13.2 \pm 0.74$ & 0.312 \\
\hline 10 weeks & $14.1 \pm 0.74$ & $14.4 \pm 0.81$ & $15.3 \pm 0.20$ & $15.1 \pm 0.59$ & 0.377 \\
\hline 12 weeks & $16.2 \pm 0.88$ & $16.2 \pm 0.73$ & $17.1 \pm 0.76$ & $16.8 \pm 0.43$ & 0.409 \\
\hline 14 weeks & $18.1 \pm 0.69$ & $18.0 \pm 0.66$ & $19.1 \pm 0.53$ & $18.8 \pm 0.76$ & 0.534 \\
\hline 16 weeks & $19.8 \pm 1.11$ & $19.6 \pm 1.02$ & $20.5 \pm 1.01$ & $20.4 \pm 1.08$ & 0.520 \\
\hline
\end{tabular}

The growth curve shown in Figure (3) indicate a relatively stable increase in live body weight throughout the 16-week period supporting contention (Farid et al., 2005b) that as milk production decreased and weights increased the lambs shared the diets offered to the dams especially the concentrates (and possibly hay) and in particular beyond the age of eight weeks.

Growth rates calculated during two-weeks between birth and weaning, least-square means are summarized in Table (8) and Figure (4). In general, growth was particularly fast between 4 and 8 weeks in the control lambs group. But, the fast growth for 20, 40 and 60\% ALH lamb groups started early between 2 and 8 weeks.

Table (8): Pre-weaning growth rates of lambs (g/day). 


\begin{tabular}{|c|c|c|c|c|c|}
\hline \multirow{2}{*}{ Item } & \multicolumn{4}{|c|}{ Experimental Diets } & \multirow{2}{*}{ P-value } \\
\hline & Control & $20 \%$ ALH & $40 \%$ ALH & $60 \%$ ALH & \\
\hline Birth weight, $\mathrm{Kg}$ & $3.4 \pm 0.21$ & $3.3 \pm 0.19$ & $3.4 \pm 0.25$ & $3.5 \pm 0.27$ & 0.095 \\
\hline Bir. - 2 weeks & $100.0 \pm 0.11$ & $114.3 \pm 0.14$ & $135.7 \pm 0.13$ & $150.0 \pm 0.14$ & 0.344 \\
\hline 2 - 4 weeks & $150.0 \pm 0.15$ & $185.7 \pm 0.16$ & $185.7 \pm 0.10$ & $192.9 \pm 0.20$ & 0.502 \\
\hline 4 - 6 weeks & $185.7 \pm 0.10$ & $185.7 \pm 0.12$ & $185.7 \pm 0.13$ & $185.7 \pm 0.15$ & 0.464 \\
\hline $6-8$ weeks & $164.3 \pm 0.14$ & $164.3 \pm 0.14$ & $185.7 \pm 0.15$ & $164.3 \pm 0.19$ & 0.481 \\
\hline $8-10$ weeks & $157.1 \pm 0.18$ & $142.9 \pm 0.16$ & $157.1 \pm 0.10$ & $135.7 \pm 0.14$ & 0.543 \\
\hline $10-12$ weeks & $150.0 \pm 0.15$ & $128.6 \pm 0.13$ & $128.6 \pm 0.12$ & $121.4 \pm 0.17$ & 0.483 \\
\hline $12-14$ weeks & $135.7 \pm 0.11$ & $128.6 \pm 0.17$ & $142.9 \pm 0.14$ & $142.9 \pm 0.11$ & 0.511 \\
\hline $14-16$ weeks & $121.4 \pm 0.14$ & $114.3 \pm 0.13$ & $100.0 \pm 0.14$ & $114.3 \pm 0.18$ & 0.376 \\
\hline Average daily gain & $147.3 \pm 0.19$ & $145.5 \pm 0.18$ & $152.7 \pm 0.20$ & $150.9 \pm 0.17$ & 0.436 \\
\hline
\end{tabular}

The present results of daily growth gain indicate that the graded levels of ALH (dried Acacia saligna leaves) inclusion instead of berseem hay did not significantly $(\mathrm{P}>0.05)$ affect daily gain. The average total daily gain for the experimental lamb groups are 147.3, 145.5, 152.7 and 150.9 g/day for control, 20, 40 and $60 \%$ ALH lamb groups, respectively. These values of lamb's daily gain are almost equal to the recorded daily gain value $150 \mathrm{gm} /$ day for lambs born for Barki ewes fed $30 \%$ berseem hay plus ad lib rice straw and below the value $160 \mathrm{~g} /$ day for lamb groups born for Barki ewes fed according to the recommended allowances of NRC (1985), (Farid et.al.,2005c).

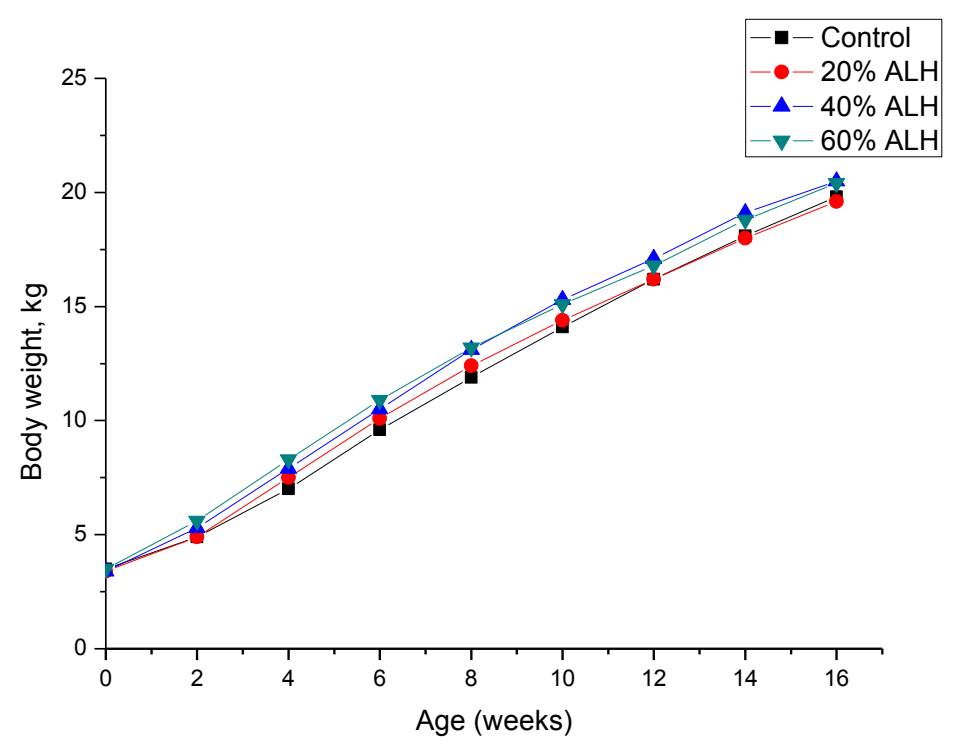

Figure (3): Lambs weight gain from birth to weaning (16 weeks, Kg). 


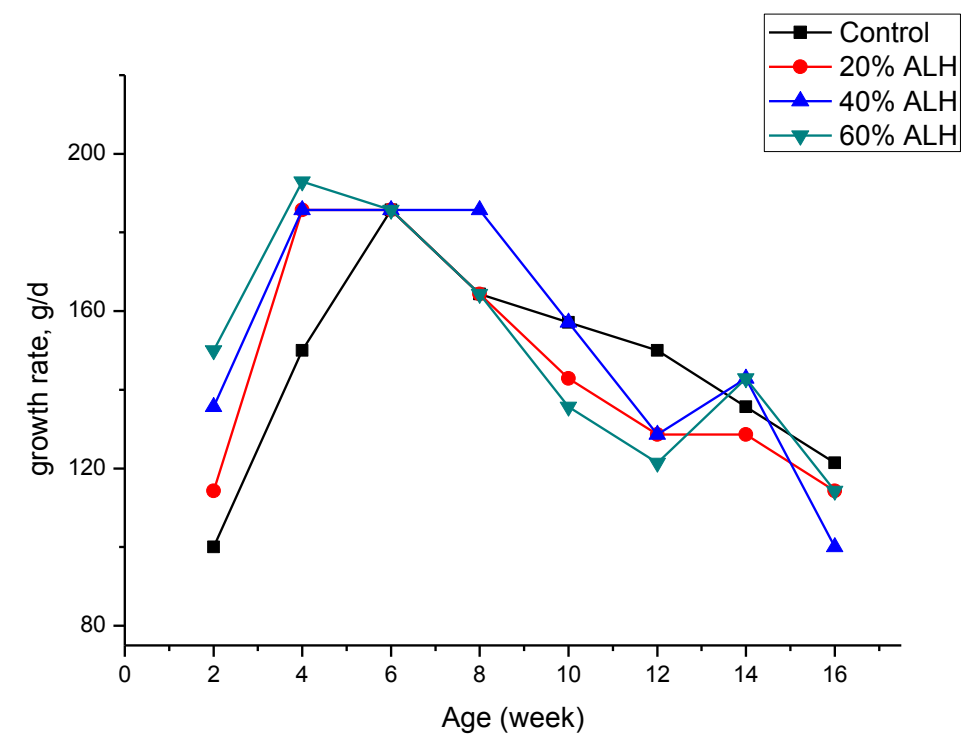

Figure (4): Pre-weaning growth rates of suckling lambs (g/day).

It is little known about the effect of feeding Acacia saligna component on pregnant ruminant animals and offspring birth weight and daily weight gain from birth to weaning. Menenses et al. (2012) conducted a study to evaluate production response of goats during pregnancy and lactation when fed Acacia saligna (Labill.) H.L. Wendl. forage as an alternative feed supply during dry periods. Pregnant goats were received $0,25,50,75$, and $100 \%$ Acacia component: leaf, and small $(<4 \mathrm{~mm})$ and large steam $(>4 \mathrm{~mm})$ as an alfalfa (Medicago sativa L.) hay replacement with no concentrates. They reported that birth weight varied with Acacia as the only forage $(\mathrm{P}<0.05)$. The birth weights obtained were 2.89 and $3.29 \mathrm{~kg}$ for goat's females and males, respectively, with an average of $3.14 \mathrm{Kg}$. This average birth weight is lower than the lambs birth weights recorded in the present experiment. These differences may be due to animal species and feeding regimen. Also, they indicated that, the type of kidding also did not vary $(\mathrm{P}>0.05)$. The values were $3.4,3.18$, and $2.7 \mathrm{~kg}$ for single, twin, and triplet births, respectively. They also, concluded that, although the partial inclusion of acacia produced only a tendency toward lower birth weights, it is necessary to consider nutrient intake reduction; the ME deficit, and the effect on body condition, particularly at birth, which may affect birth weight; and because the type of kidding and sex did not show conclusive results.

On the other hand, the phenolic and tannin composition content of Acacia (Degen et al., 1995) may reduce nutrient absorption due to fixing, especially of proteins. This led us to conclude that the use of Acacia in goat diets during the last third of pregnancy has limitations and that as a consequence of the body condition response; Acacia should not be included in percentages higher than $26 \%$ of total DM intake to avoid negative effects on production. This result seems to be comparable to our present results that inclusion $60 \%$ Acacia instead berseem hay showed a positive effect on production, whereas this level represent about $24 \%$ of total DM intake.

\section{CONCLUSION}

Supplementation of dried A. saligna leaves to lactating ewes did not affect the daily dry mater intake and milk yield and composition. A. saligna can easily grow in the tropical and sub-tropical areas where feed deficiency is a critical problem. Hence, dried A. saligna leaves can be used as alternative feed sources for lactating sheep especially during dried and semi-dried seasons.

\section{REFERENCES}


AOAC (1995). Official Methods of Analysis (15th ed.). Association Official Analytical Chemists. Washington, Virginal 1, USA.

Atti, N. and H. Rouissi (2003). Effets de la complémentation sur la production laitière des brebis SiciloSarde en pâturage de l'orge en vert et de la vesce. Ann.

Barry, T.N. and S.J. Duncan (1984). The role of condensed tannins in the nutritional value of Lotus pedunculatus for sheep. 1. Voluntary intake. Br. J. Nutr. 51, 484-491.

Barry, T.N. and T.R. Manley (1984). The role of condensed tannins in the nutritional value of Lotus pedunculatus for sheep. 2. Quantitative digestion of carbohydrates and proteins. Brit. J. Nutr. 51, 493504.

Barry, J.N., and W.C. McNabb (1999). The implication of condensed tannins on the nutritive value of temperate forages fed to ruminants. The British Journal of Nutrition. 81, 263-272.

Barry, J.L. and D. Tome (1991). Formaldehyde content of milk in goats fed formaldehyde treated soybean oil-meal. Food Addit. Contam. 8 (5), 633-640.

Ben Salem, H., H.P.S. Makkar, A. Nefzaoui, L.Hassayoun and S. Abidi (2005). Benefit from the association of small amounts of tannin-rich shrub foliage (Acacia cyanophylla Lindl.) with soya bean meal given as supplements to Barbarine sheep fed on oaten hay. Anim. Feed Sci.Tech. 122, 173-186.

Ben Salem, H., A. Nefzaoui and L. Ben Salem (2002). Supplementation of Acacia cyanophylla Lindl. Foliage-based diets with barely or shrubs from arid areas (Opuntia ficus-indica F. inermis and Atriple nurnmularia L.) on growth and digestibility in lambs. Anim. Feed Sci. Technol., 96: 15-30.

Ben Salem, H., A. Priolo, and P. Morand-Fehr. (2008). Beneficial and detrimental effects of dietary condensed tannins for sustainablesheep and goat production- Progress and challenges. Animal Feed Science and Technology 147:116-139.

Bocquier, F. and G. Caja (2001). Production et composition du lait de brebis: effets de l'alimentation. INRA Prod. Anim. 14 (2), 129-140.

Buckley, K.E., L.J. Fisher and V.G. Mackay (1988). Levels of aldehyde in milk, blood and tissues of dairy cows and calves consuming formalin-treated whey. J. Agri. Food Chem. 36, 1146-1150.

Degen, A., K. Becker, H. Makkar and N. Borowy (1995). Acacia saligna as a fodder tree for desert livestock and the interaction of its tannins with fibre fractions. Journal of the Science of Food and Agriculture 68:65-71.

Duncan, D.B. (1955). Multiple ranges and multiple F- test. Biometrics. 11: 1 - 42.

D'Urso, G., M. Avondo and L. Biondi, (1993). Effect of supplementary feeding on grazing behavior of Comisana ewes in a Mediterranean semi-extensive production system. Anim. Feed Sci. Technol. 42, 259-272

Farid, M.F.A., H.S. Khamis, E.Y.A. Eid and A. Helal (2005a). Feeding management and the performance of sheep in southern Sinai. 1. Diet selection and voluntary food intake of ewes. Journal of Agricultural Sciences, Mansoura University, 30 (12): 7437-7456.

Farid, M.F.A., H.S. Khamis, E.Y.A. Eid and A. Helal. (2005b). Feeding management and the performance of sheep in southern Sinai. 2. Reproduction and production performance of the ewe. Journal of Agricultural Sciences, Mansoura University, 30 (12): 7457 - 7476.

Farid, M.F.A. H.S. Khamis, E.Y.A. Eid, R.A. Ahlam and A. Helal. (2005c). Feeding Management and the Performance of Sheep in Southern Sinai: 3. The Lambs Pre-And Post-Weaning. J. Agric. Sci., Mansoura Univ., 30 (12): 7477 - 7494.

Frutos, P., G. Hervás, F.J. Giráldez and A.R. Mantecón (2004).Tannins and ruminant nutrition. Review. Span. J. Agric. Res., 2, 191-202.

Kearl, L.C. (1982). Nutrient Requirements of Ruminants in Developing Countries. International Feedstuffs Institute (IFI), Utah State University, Logan.

Krebs, G.L., D.M. Howard and K. Dods (2007). Feeding Acacia saligna to sheep and goats with or without the addition of urea or polyethylene glycol. Asian Australasian Journal of Animal Sciences 20:1551-1556. 
Lapierre, H., R. Berthiaume and P. Dubreuil (2002). Equilibrer les rations pour lesacides aminés : rêve ou réalité. 26ème Symposium sur les bovins laitiers. CRAAQ. Université de Sherbrooke, pp. 12-29.

Maamouri, O., N. Atti, K. Kraiem and M. Mahouachi (2011). Effect of concentrate and Acacia cyanophylla foliage supplementation on nitrogen balance and milk production of grazing ewes. Journal of Livestock science. Vol: 139 (3): Pp. 264-270.

Meneses R. R. (2004). Comportamiento de procedencias de Acacia saligna (Labill.) H.L. Wendl. en la Región de Coquimbo, Chile. Ciencia Forestal Santa María 9:103-109.

Meneses R. R., Y.V. Olivares, M.S. Martinoli and H. P. Flores (2012). Effect of feeding Acacia saligna (LABILL.) H.L. Wendl. on goats stabled during late pregnancy and lactation. Chilean Journal of Agriculture Research, 72 (4): 550-555.

Min, B.R., T.N. Barry, G.T. Attwood and W.C. McNabb (2003). The effect of condensed tannins on the nutrition and health of ruminants fed fresh temperate forages. A review. Anim. Feed Sci. Technol. 106, 3-19.

Molle, G., M. Decandia, N. Fois, S. Ligios, A. Cabiddu and M. Sitzia (2003). The performance of Mediterranean dairy sheep given access to sulla (Hedysarum coronarium L.) and annual ryegrass (Lolium rigidum Gaudin) pastures in different time proportions. Small Rum. Res. 49, 319-328.

Mora, F.and R. Meneses (2003). Efecto del riego sobre el crecimientoy producción forrajera de Acacia saligna (Labill.) H.L. Wendl. en la zona árida de Chile. CERNE 9: 257-260.

NRC (1985). Nutrient Requirements of Sheep. 6th Ed., National Academy Press, Washington D.C.

Patra, A.K. and J. Saxena (2011). Exploitation of dietary tannins to improve rumen metabolism and ruminant nutrition. J.Sci. Food Agric. 91, 24-37.

Pritchard, D.A., P.R. Martin and P.K. O'Rourke (1992). The role of condensed tannins in the nutritive value of Mulga (Acacia aneura) for sheep. Australian Journal of Agricultural Research 49:1739-1746.

Purroy, A. and C. Jaime (1995). The response of lactating and dry ewes to energy intake and protein source in the diet. Small Rum. Res. 17, 17-24.

Rouissi, H., N. Atti and M.H. Othmane (2005). Effets de l'espèce fourragère, du mode d'exploitation et de la complémentation sur les performance laitières la brebis sicilo-sarde. Ann. INRAT 78, 147-161.

SPSS (1999). "Statistical Package for Social Science "Release 11, SPSS INC, Chicago. USA.

Squella, F., R. Meneses and Y.T. Gutiérrez (1985). Evaluación de especies forrajeras arbustivas bajo condiciones de clima mediterráneo árido. Agricultura Técnica (Chile) 45:303-313.

Steinshamn, H. (2010). Effect of forage legumes on feed intake, milk production and milk quality: A review. Animal Science Papers and Reports. Vol. 28 (3), 195-206.

Terril, T.H., G.B. Douglas, A.G. Foote, R.W. Purchas, G.F. Wilson and T.N. Barry (1992). Effect of condensed tannins upon body growth, wool growth and rumen metabolism in sheep grazing sulla (Hedysarum coronarium) andperennial pasture. J. Agric. Sci. Camb. 119 (2), 265-273.

Waghorn, G.C., I.D. Shelton, W.C. McNabb and S.N. McCutcheon (1994). Effects of condensed tannins in Lotus pedunculatus on its nutritive value for sheep.2. Nitrogenous aspects. J. Agric. Sci. 123, 109.

Wang, Y., G.B. Douglas, G.C. Waghorn, T.N. Barry and A.G. Foote (1996). Effect of condensed tannins in Lotus corniculatus upon lactation performance in ewes. J. Agric. Sci. Camb. 126, 353-362.

Woodward, S.L., G.C. Waghorn, K.R. Lassey and P. Laboyre (2002). Does feeding sulla (Hedysarum coronarium) reduce methane emissions from dairy cows? Proc. New Zeal. Soc. Anim. Prod. 62, 227230.

Zegeye, T., S. Gebreyohaness and M. Kebede (2016). Effect of feeding graded level of dried Acacia Saligna leaves on milk yield and milk composition of crossbred dairy cows fed grass hay as basal diet. Journal of Biology, Agriculture and Healthcare, Vol.6, No.1, 1-20.

Vasta, V., A. Nudda, A. Cannas, M. Lanza and A. Priolo (2008). Alternative feed resources and their effects on the quality of meat and milk from small ruminants. Anim Feed Sci Technol. 147: 223-246. 


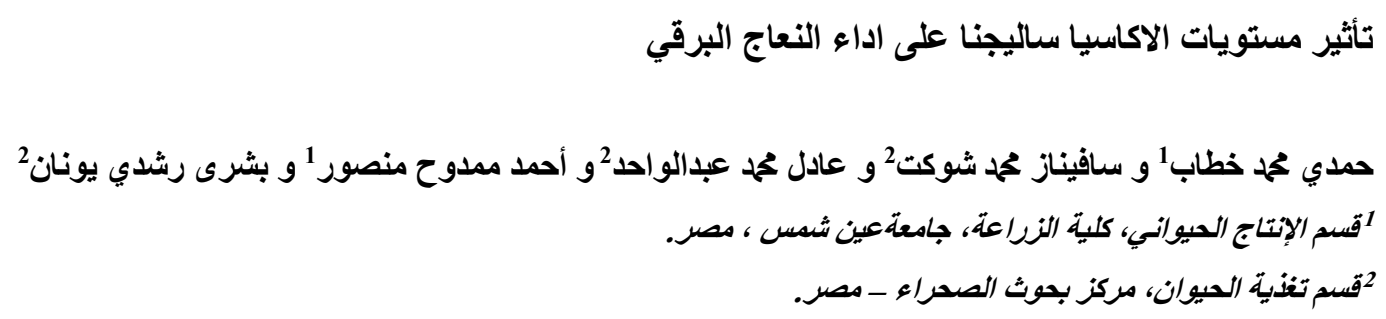

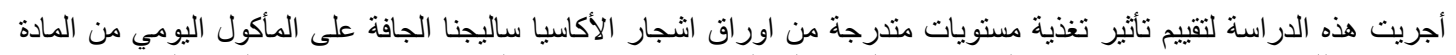

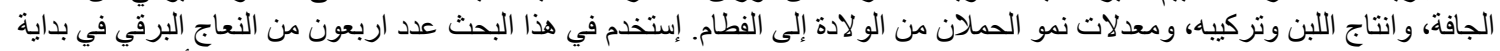

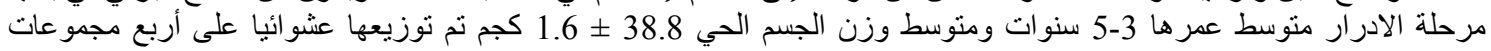

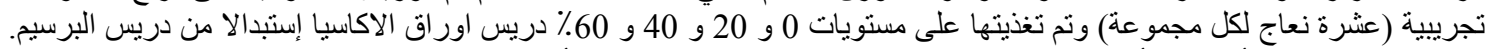

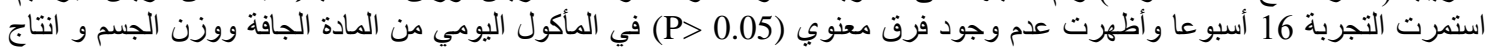

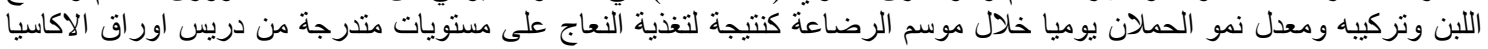

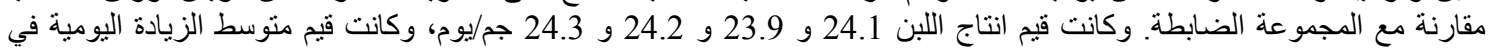

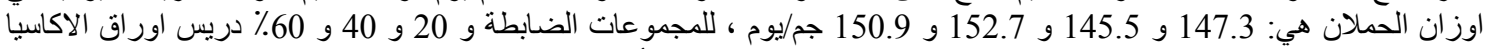
على التوالي. ويمكن ان نخلص الى ان دريس اوراق الاكاسيا سالجينا يمكن أن بستخدم كمصدر غذائي بديلا عن دريس البرسيم للنعاج 